\title{
Determinants of Loan Repayment: The Case of Microfinance Institutions in Gedeo Zone, SNNPRS, Ethiopia
}

\author{
Girma Gudde Jote \\ Accounting and Finance Department, Dilla University, Dilla, Ethiopia
}

Copyright $(2018$ by authors, all rights reserved. Authors agree that this article remains permanently open access under the terms of the Creative Commons Attribution License 4.0 International License

\begin{abstract}
The objective of this study was to identify and examine the determinants of loan repayment in MFIs in Gedeo zone, SNNPRS, Ethiopia. In fact, identifying and examining such determinant factors of loan repayment is vital in the achievement of profitability and sustainability of MFIs. Out of total population of 6662 (1610 defaulter and 5052 non-defaulter borrowers), 364 representative sample from borrowers are selected by using stratified random sampling from borrowers by dividing the borrowers in to two strata, in terms of loan payment status as defaulters and non-defaulters. In this connection, the researcher collected data from primary and secondary sources and analyzed by using binary logistic model. A total of ten explanatory variables were included in this model and out of these, six variables were found to be statistically significant to influence the probability of loan repayment. These significant variables are: educational level, method of lending, nearness of borrower's residence to the institutions, family size, and income from activities financed by loan and training. The researcher suggests that the identified significant variables to be a spring board for further interventions by Microfinance institutions, stakeholders and policy makers so as to come with a breakthrough to significantly decrease or even avoid defaulting problems. On the basis of the study findings, the researcher also provided some recommendations that are vital to reduce loan repayment problems and improve loan repayment performance of borrowers in the study area. These includes: proper training, continuous supervision, enough loan officers or committee and technical support for borrowers on profitable business activities.
\end{abstract}

Keywords Microfinance Institution, Loan Repayment, Defaulters and Non-defaulters

\section{Introduction}

Poverty alleviation has been one of the key development challenges over the decades in most developing economies. One of the identified key constraints faced by the poor is lack of access to formal credit. Microfinance institutions were established to fill the gap of scarce finance resources by providing funds to the poor and lower income group to alleviating poverty and enhance their business activities. Different approaches have been employed in alleviating poverty; the one is provision of credit for targeted poor. Credit is considered to be an essential input to increase productivity [38].The central provision of microfinance is delivery of small loans [13].

Microfinance can be a critical element of an effective poverty reduction strategy. Well organized access and efficient provision of saving, credit and insurance facilities in particular can enable the poor to smooth their consumption, manage their risks better, build their assets gradually, develop their microenterprise, and enhance their income earning capacity. Thus, microfinance helps to promote economic growth and development [8].To this end, the current study has tried to identify and examine determinants of loan repayment in MFIs in Gedeo zone, SNNPRS, Ethiopia.

\subsection{Statement of the Problem}

The primary objective of MFIs is to provide financial services (credit and saving) to the poor in order to relieve financial constraints and help alleviate poverty. Microfinance institutions offer loans mostly to urban and rural peoples who cannot afford collaterals to get loans from banks. Financial services in Ethiopia are characterized by a high urban concentration. To fill these gap microfinance institutions, provide credit to the poor, who lack access of formal credit from financial institutions.

Although the performance of the MFIs in Ethiopia has been impressive since their establishment, they are not free of default problems [55].[28] argued that default problems destroy lending capacity as the flow of 
repayment declines, transforming lenders into welfare agencies, instead of a viable financial institution. Loan default may also deny new applicants access to credit as the microfinance institutions management problems augment in direct proportion to the increasing default problem. One indicator of effective MFIs is the loan performance of the borrowers [49]. High repayment rates are associated with the benefits for both MFIs and borrowers [24]. If there is high repayment rate, the relationship between the MFIsand their clients will be good [18]. In contrast, if there is low repayment rate, both the borrowers and MFIs will be adversely affected. So, if the MFIs are not viable because of default problem, borrowers will not have access to loan and suffer from poverty, which affects the development of the country as whole.

According to [54], the most common and often the most serious vulnerability in microfinance institution is the chance that a microfinance institution (MFI) may not receive its money back from borrowers (plus interest). The sustainability of microfinance institutions depends largely on their ability to collect their loans as efficiently and effectively as possible. In other words, to be financially viable or sustainable, microfinance institutions must ensure high portfolio quality based on $100 \%$ repayment, or at worst low delinquency/default, cost recovery and efficient lending [4].

Nowadays, high percentage of loans that are in arrears is one of the key issues facing the microfinance industry. In order for micro finance institutions (MFIs) reach scale and move towards operational and financial sustainability, arrears rate must be reduced. High delinquency rates in credit programs for the poor were often blamed on poor market infrastructure, deficient business income and client's misallocation of loan funds to consumptions activities (Rural Financial Intermediation Program [45].

MFIs must reach at the position of high repayment rate, as high loan repayment rate benefits both MFIs and the borrowers. Every microfinance institution tries to maximize its repayment performance. Improving repayment rate helps reduce the dependence of the MFIs on subsidies, which would improve sustainability [24]. One indicator of effectiveness of MFIs is the loan repayment performance of the borrowers [5].It is also argued that high repayment rate reflects the adequacy of MFIs' services to clients' needs and restrict the cross subvention of the borrowers [24]. For borrowers, high repayment rate helps to obtain the next higher amount of loan [18]. Contrary to this, if there is low repayment rate, both the borrowers and the MFIs will be affected. In this case, the borrowers will not be able to obtain the next higher loan and the lenders will also lose their customer.

In order to maintain sustainability of those MFIs, examining determinant factors influencing loan repayment is important, because if borrowers do not repay, then there may not be sufficient funds to ensure that the liquidity position of the MFI is maintained. When there is a loss in the MFI liquidity due to high levels of non-repayment, the cyclical flow of funds between the MFI and the borrowers will be interrupted [38].

Studies on loan repayment are not a new research area. In fact, various researches have conducted in loan repayment performance in different time, but the results of findings are still debatable among different researchers. The findings show there is inconsistency of result regarding the determinant factor variables. Some variables such as sex, education level, method of lending and loan size have debatable results. For instance; Bhatta and Tang [17] and [51] found sex has significant impact on repayment rate, whereas [24] opposes this result. Regarding loan size, [59] found as loan size have positive impact on loan repayment.

Whether default is random and influenced by erratic behaviors or whether it is influenced by certain factors in specific situations, therefore, needs an empirical investigation so that findings can be used by Microfinance Institutions to manipulate their credit programs for the better [31]. Hence, this study aims to fill the above-mentioned gaps by identifying and examining determinants of loan repayment in MFIs in Gedeo zone, SNNPRS, Ethiopia.

\subsection{Objectives of the Study}

The main objective of the study is to identify and examine determinants of loan repayment in Microfinance institutions in Gedeo zone.

In line with above general objective, the specific objectives of the study are:

1. To examine the major demographic factors such as educational level, family size, and residence of borrower, that impact loan repayment by the borrowers of MFIs.

2. To investigate the main loan factors like loan size and interest rate, that influence loan repayment performance of borrowers of MFIs.

3. To examine the key economic factor like income from activities financed by the loan that affect loan repayment performance of borrowers of MFIs.

4. To assess the main institutional factors like training and method of lending that influence loan repayment performance of borrowers of MFIs.

5. To investigate whether the cultural factors such as loan diversion rate, and celebration and participation on social festivals have impact on loan repayment performance of borrowers of MFIs.

\subsection{Research Hypothesis}

H1: Education is significantly associated with loan repayment of MFIs.

H2: Method of lending is significantly associated with 
loan repayment of MFIs' borrowers.

H3: Celebration and participation on social festivals is significantly associated with loan repayment of MFIs' borrowers.

H4: Nearness to borrower's residence is significantly associated with loan repayment of MFIs' borrowers.

H5: Family size is significantly associated with loan repayment of MFIs' borrowers.

H6: There is significant association between income from activities financed by loan and loan repayment of MFIs' borrowers.

H7: There is significant association between training and loan repayment of MFIs' borrowers.

H8: There is significant association between loan diversion rate and loan repayment of MFIs' borrowers.

H9: Loan size is significantly associated with loan repayment of MFIs' borrowers.

H10: There is significant association between interest rate and loan repayment of MFIs' borrowers.

\section{Review of Related Literature}

\subsection{Determinant Factors Affecting Loan Repayment}

\subsubsection{Demographic Factors}

Education level: [50] assessed the determinants of loan repayment performance. The educational level coefficient had a positive sign indicating that education has direct relationship to the repayment rate and this showed that as level of education increases, borrowers enhances their ability to access, evaluate, and understand new production techniques. This underpins the assertion that educated farmers are more amenable to risk taking and change than the non-educated ones. The result of this study showed that the higher the literacy level of the clients, the higher will likely be non-default.

[30] Fount result that showed education was important and significant factor that enhances the loan repayment performance. As per [3], education affects loan repayment positively. In addition, [48] found out that education is important and significant factor that enhances the credit repayment performance. [53] also found that educational status is significant determinants of the probability of loan repayment.[34]conducted a study on the factors affecting loan repayment performance. They found that education is an important determinant of loan repayment. An educated client is able to use modern technologies, perform farming activities based on cropping calendar, and manage resources properly. All these factors boost production, which improves loan repayment.

[1] studied factors that influence micro finance and loan repayment performance with particular reference to the Oromia Credit and Savings Share Company (OCSSCO) in Kuyu, through the application of descriptive statistics and the probit model. His finding shows that education is important and significant factors that enhance the loan repayment performance. [41] Studied factors that determine loan repayment decision among farmers in Southwestern Nigeria during 2005. Data from 180 respondents were collected through multistage sampling technique. Tobit regression result showed education as important factors in determining loan repayment and reducing loan default.

Nearness of borrower's residence to institutions: [26] clearly showed that $69.16 \%$ of the defaulter respondents' residence and businesses were near Harari Microfinance institutions, whereas $30.84 \%$ were not near to Harari MFI. As a result, distance of borrowers from the offices doesn't affect the loan repayment rate of borrowers. This implies being far and/or near to the Microfinance institutions was not related to the loan repayment performance and thereby to loan default. [1] Also indicated that the distance of borrowers from institutions don't have significant impact on the loan repayment problem. However, [12] found that distance of borrowers has significant effect on the loan default.

Family size: [41] have analyzed the determinants of repayment decision among small holder farmers in Southwestern State of Nigeria. The result showed that borrowers with lower number of household members would meet their repayment obligation better than those with high number of household members. [7]argued that family size had negative influence on the level of loan repayment. The result of the model showed that family size was statistically significant factor influencing timely loan repayment performance positively [2]. However, [15] argued that family size had insignificant effect on loan repayment performance of smallholder farmers. [53]found that number of dependents supported by borrower was significant determinant of the probability of loan repayment.

\subsubsection{Economic Factor}

Income from activities financed by the loan: [48] found out that income from activities financed by the loan is important and significant factor that enhances the credit repayment performance. [53] found that income from the loan activities financed by institution is significant determinant of the probability of loan repayment.[30]analyzed the microfinance repayment performance of Oromia Credit and Saving Institution (OCSI) in Kuyu, Ethiopia. According to his finding income from activities financed by loan is positively and significantly related to loan repayment performance and thereby reduces loan default.

\subsubsection{Cultural Factors}

Celebration and participation on social festivals: According to [15], expenditure for social festivals was found to have insignificant effect on loan repayment performance of smallholder farmers. [14]found that 
celebrating social festival can negatively influence loan repayment performance.

Loan diversion rate: [30] analyzed the microfinance repayment performance of Oromia Credit and Saving Institution (OCSI) in Kuyu, Ethiopia. According to his finding, loan diversion is significant and negatively related to loan repayment rate. The negative sign implies that the use of diverted funds for non-income generating purposes. [48] argued that credit diversion was found to be significantly increase credit default.

\subsubsection{Loan Factors}

Loan size: [42] carried a study on determinant of loan repayment performance in Southeast State of Nigeria. They hypothesized that loan size to have a negative relationship with repayment rate. In other words, the higher the loan size given by the institution, the lower was the repayment rate of the clients. Their regression results strongly disagreed with this hypothesis. It stipulated that the higher the size of the loan to clients, the higher the repayment rate. This situation appears to be most unlikely because the amount to be repaid was relatively larger and if the loan was from development oriented institution with subsidized interest rate and little chance of repeat loans, the pressure or inclination of such clients would be to delay repayment.

[37] described micro finance credit lending terms and repayment performance and stated the loan sizes in most cases affect the nature of business and type of investment for the borrowers. The small loan size is often advanced by the micro finance institutions as a way of minimizing risks. However, when the clients are not given adequate funds to cater for their business needs, they tend to resort to multiple borrowing. This in turn affects their repayment and increases the risks of the loan. The respondents were divided as to whether Brac Uganda is giving them enough credit to cater for their business needs with some indicating that it was enough while others indicated that it was not.

[32]found that received loan size has positive effect on repayment performance of recipients. The study result of [40] showed that amount of loan obtained by farmers was the major factors that positively and significantly influenced loan repayment. [7] obtained that the amount of loan granted to farmers have major significant positive influence loan repayment. Among the determinants of loan repayment of microfinance institutions, loan size had positive impact on loan repayment [42].

According to [30] loan size was found to be significantly increase loan default. [48] suggested that credit/loan size was found to negatively influence the borrowers' loan repayment performance. [53] found that loan size was significant determinant of the probability of loan repayment. But, [15] studied the determinants of loan repayment performance of smallholder farmers in North Gondar, Ethiopia. His finding revealed that loan amount was found to have insignificant effect on loan repayment performance.

Interest rate: [35] argued that high interest rate caused delay in repayments of agricultural credit.[32]studied the factors influencing on repayment performance of farmers in Khorasan-Razavi province of Iran during 2008. The logit model was used to explain the probability of loan on time repayment as a result of any of the identified independent variables. The signs of the coefficient of independent variables and significance of the variables were used determining largely the impact of each variable on probability of dependent variable. His study's result shows that loan interest rate implies a negative effect on repayment performance of recipients. By another way, as the loan interest rate increases the probability of loan default increases and thereby, negatively affects loan repayment performance of borrowers.

\subsubsection{Institutional Factors}

Method of lending: Many of the MFIs in Ethiopia provide similar financial products and use predominantly the group lending methodology, while individual lending is employed to a limited extent [11]. Because group lending methodology addresses the asymmetric distribution of information by transferring the burden of default risk to the contracting borrowers, thus transfers the costly screening to be done by the borrowers themselves. Screening borrower's risk is critical since, it affects loan repayment and lenders profit thereby. Group lending schemes induce borrowers to engage in assortative matching wherein local knowledge about each other's assets, capabilities, character traits are used to sort and self-select [43].

[20] theoretically shows that without sequential financing, group lending may suffer from under-monitoring with borrowers investing in risky projects. The most important factor inciting lending groups to repay is the relative value they attach to access to future credit [21].[33] find that MFI tends to choose group lending when its main market is rural, when it prefers female borrowers, and when the average loan amount is small. The studies show that group-based lending approach cannot ensure high repayment rate in MFIs.

In the view of [46], group lending will also minimize loan default. Many microfinance institutions borrow in groups and choose to lend to groups of borrowers rather than on an individual basis. As opposed to this, the microfinance institutions provide the loans so that the borrowers are not limited to the money that they themselves can contribute. The general organization of group lending consists of a group of borrowers who work together, support, and mentor one another to maximize the impact that the loan can have on each individual. Additionally, in many group lending situations, the members of the group are responsible for selecting new 
members and for the timely repayment by other members, known as joint liability. As a result, group lending tends to lead to superior performance by the borrowers in operating their businesses and better rates of loan repayment.

Several studies have been performed on the group lending aspect of microfinance, and most research shows it to be an effective method. [56]builds on the theory that group lending leads to improved performance by the borrowers. He explains that in additional to the support and guidance from the group, there is also a strong incentive for each individual to operate effectively due to one's personal reputation within the group. Furthermore, since groups generally are formed of members from the same village or community, repaying loans on time and in full affects borrowers standing within the community at large, not limited to the lending group. However, while this social effect can produce positive outcomes for the microfinance institutions, some researchers believe that it can lead to an unhealthy social environment.

The general consensus in the literature on group lending and group liability is that group lending benefits both the borrowers and the institutions. The borrowers receive the additional support and assistance from a group of individuals dealing with the same types of issues. Furthermore, the institutions are able to lower costs by relying on the lending groups to provide these services that otherwise would be required from the institution itself. Group lending also works to move institutions into a more client-led realm, which has proven to be more effective in creating sustainable development programs.

In microfinance institutions credits are provided in group. The main characteristic of group lending is joint liability. This means that all group members are treated as being in default if any one member of the group does not repay the loan. In group liability, there are both positive and negative effects. The positive effect is that the successful borrowers may repay the loan of partners who obtain sufficiently poor returns to make repayment profitability. The negative effect arises if the entire group defaults, when at least some members would have repaid had they not been saddled with the weight of liability for their partners' loans [16]

Training: the finding of [52] stated that one of the important requirements for the success of microfinance institutions is to create awareness to potential clients by giving appropriate training to borrowers about loan utilization, loan terms and obligations. In addition, [6] agreed on the loan utilization and technical training should be given to improve the skill of potential and actual clients. Technical support is important to increase the productivity of borrowers.

Training is one the important requirements for the success of Microfinance institutions [12]. If lender provides various training, the clients will able to understand the rules and regulations easily. They also develop the skill how to do business and money utilization. Training is needed not only for clients, but also for loan officers. In both cases, it has positive contribution to the repayment rate. [39] also agrees on the importance of training due to decreasing default rate. Among the determinants of loan repayment of microfinance institutions, training duration had positive impact on loan repayment [42].But, [55] study reveals that there is statistically insignificant association between training and loan repayment performance because the training may not be continuous, relevant, timely and not catering the borrowers' requirement.

\subsection{Conceptual Framework of Determinants of Loan Repayment}

According to [36] conceptual framework involves forming ideas about relationships between variables in the study and showing these relationships diagrammatically. This study adopted the conceptual framework as shown in figure 1 which demonstrates the conceptual framework of the relationship between the dependent variable (loan repayment) and the independent variables (the determinant factors affecting loan repayment performance of Microfinance institution's loan beneficiaries).

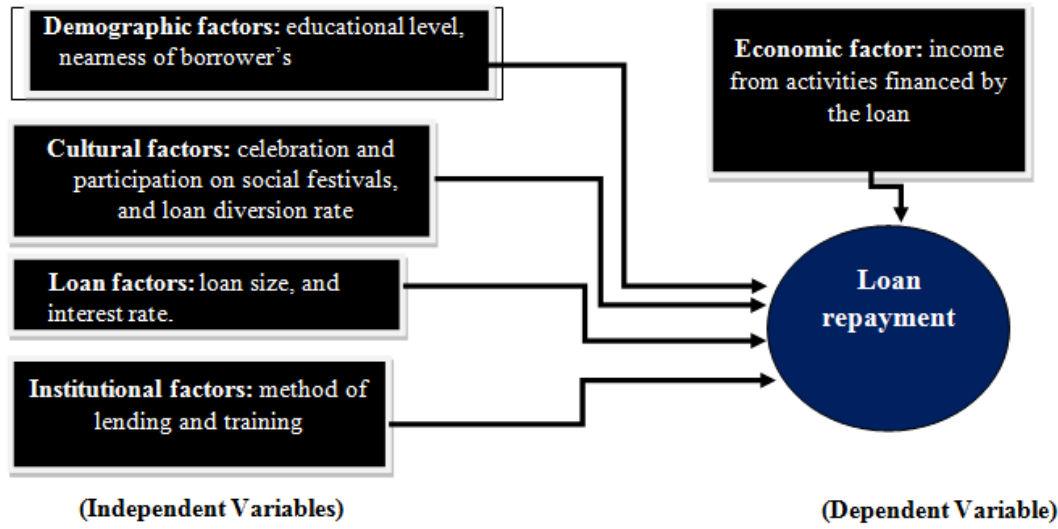

Source: Researcher's construct (2017)

Figure 1. Conceptual Framework of the study 


\section{Research Methodology}

\subsection{Research Approach}

Research design is about the specific research strategy that the researcher adopts to solve the research problem [19]. There are two types of research designs. These include the qualitative and the quantitative designs [23]. In view of their numerous benefits in achieving the stated research objectives and in testing research hypothesis properly, the researcher has used both qualitative and quantitative research designs in this study.

\subsection{Data Source and Type}

One of the outstanding features of research is the decision around who to collect the research data, from and in what ways the research data should be gathered. This study was conducted based on both primary and secondary data. The primary data were collected by structured questionnaires and face to face interviews.

The researcher used a questionnaire as the main tool for gathering data for analysis. The questionnaires of this study included both closed and open-ended questions. The questionnaires were prepared in English language and translated into Amharic to facilitate proper responses from respondents. The questionnaires were pre-tested by pilot study before conducting survey for the whole sample. In addition, qualitative data have been collected through semi-structured interview. Direct communication with the managers of MFIs in the study area form part of the personal interviewing process; the interviewer poses questions to the managers in a face-to-face interviewing process.

Secondary sources include published and unpublished materials about microfinance institution's activities. Secondary data forms part of the scientific data that have been gathered in the past. In this study, through an extensive literature study, the researcher was able to gather secondary data sets to be analyzed. As a result, relevant global and national literatures on the research topic were reviewed for two reasons, to enhance the quality of questions to be included in the questionnaires and to gather highly credible primary data for analysis.

\subsection{Target Population of the Study}

The population for this study is borrowers of OmoMFI Dilla branch, Letta MFI Dilla branch, Vision Fund MFI Dilla branch and Vision Fund MFI Yirgacefe branch. The number of borrowers' data was collected from borrower profile of the institutions. During data collection period, borrowers have been classified as defaulter and non-defaulter. Currently, the institutions have 6662 borrowers. Hence, the total population of the study is 6662 borrowers.

\subsection{Sampling Techniques and Sample Size Determination}

The researcher employed stratified sampling in selecting the representative's borrowers following the method of proportional allocation under which the sizes of the samples from different strata are relatively kept proportional to the sizes of the strata. The sample for this study consists of defaulter and non-defaulter loan beneficiaries responding to the questionnaires.

As per loan list survey, out of total 6662 borrowers, 1610 borrowers are defaulter and 5052are non-defaulter borrowers. To develop the sampling size, lists of borrowers were acquired from the entire four microfinance borrowers profile list. Representative sample are selected from the total borrowers by using stratified sampling technique dividing the borrowers (population) in to two strata, in terms of loan payment status as defaulters and non-defaulters.

[57] sample size determination formula was adopted to decide sample size of borrowers for this study. The number of borrowers was 1610 defaulters and 5052 non-defaulters, totally the target study size comprised of 6662 loan beneficiaries. To select representative sample from this population, first, the initial sample size was determined by using the following scientific formula:

$$
\mathrm{n}_{0}=\mathrm{z}^{2} \alpha / 2 * \mathrm{p} \mathrm{q} / \mathrm{e}^{2}
$$

Where $\mathrm{z}=$ value for selected alpha level of 0.025 in each tail (for 95\% degree of confidence) $=1.96$, (p). (q) $=$ estimate of variance $=0.25, \mathrm{e}=$ the desired level of precision (i.e., the margin of error), $p$ is the estimated proportion of the population which has the attribute in question, $q=1-p$.

$$
\begin{gathered}
\mathrm{n}_{0}=\frac{(1.96)^{2} * 0.5 * 0.5}{0.05^{2}} \\
=385
\end{gathered}
$$

Since the initial sample size (385) is greater than $5 \%$ of the total population $(5 \% * 6662=333)$, Cochran's $(1977)$ correction formula have been used to calculate the final sample size. This calculation was done as follows:

$$
\begin{gathered}
\mathrm{n}=\mathrm{n}_{0} / 1+\left(\mathrm{n}_{0}-1 / \mathrm{N}\right) \\
=385 / 1+384 / 6662 \\
=\underline{\underline{364}}
\end{gathered}
$$

Where, ' $\mathrm{N}$ ' is the total population (6662) and ' $\mathrm{n}$ ' is sample size of the study. The researcher has selected 364 from borrowers as per stratified sampling. This sample size can be used as representative of the microfinance institutions' beneficiaries, because of borrowers under similar strata have homogenous characteristics and have common environment in which they exposed for similar problems. 
These samples from borrowers (364) were selected from each Stratum using relative proportionate allocation in relation to the percentage of total population. Hence, from the above two strata (defaulters and non-defaulters' borrowers), proportionate sample size was taken. The reason for using proportionate sample is to give equal chance for all respondents.

To determine sample size from each stratum, the following sample size determination formula has been used:

$$
\mathrm{n}_{\mathrm{h}}=\mathrm{Nh} / \mathrm{Ns} * \mathrm{n}
$$

Where: $\mathrm{n}_{\mathrm{h}}=$ sample size from each stratum, $\mathrm{N}_{\mathrm{h}}=$ Total population in each stratum, Ns=Total population of the sum of strata for study and $\mathrm{n}=$ Total sample size from the study population [29]. Based on this formula, sample size from each stratum is provided in the table below.

Table 1. Proportionate sample size from each stratum

\begin{tabular}{|c|c|c|c|c|c|c|}
\hline \multirow[b]{2}{*}{ Name of MFI } & \multicolumn{2}{|c|}{$\begin{array}{l}\text { No. of borrowers in terms } \\
\text { of loan repayment status }\end{array}$} & \multirow{2}{*}{$\begin{array}{l}\text { Total no. } \\
\text { Of } \\
\text { borrowers }\end{array}$} & \multicolumn{3}{|c|}{ Proportionate sample size } \\
\hline & Defaulters & Non- defaulters & & Defaulters & Non-defaulter & Total \\
\hline Omo MFI Dilla branch & 200 & 1345 & 1545 & 11 & 73 & 84 \\
\hline Letta MFI Dilla branch & 155 & 1312 & 1467 & 9 & 72 & 81 \\
\hline $\begin{array}{l}\text { Vision Fund MFI Dilla } \\
\text { branch }\end{array}$ & 450 & 1200 & 1650 & 24 & 66 & 90 \\
\hline $\begin{array}{l}\text { Vision Fund MFI } \\
\text { Yirgacefe branch }\end{array}$ & 805 & 1195 & 2000 & 44 & 65 & 109 \\
\hline Total & 1610 & 5052 & 6662 & 88 & 276 & 364 \\
\hline
\end{tabular}

Source: Author's computation, 2017

\subsection{Econometric Model Specification}

Loan repayment is a dependent variable, while different demographic, institutional, loan, economic and cultural factors are considered as independent variables. In this study, the dependent variable assumes values 0 and 1 , which is 0 if the borrower is a defaulter and 1 if the borrower is non-defaulter. Therefore, loan repayment is treated as dichotomous dependent variable and a non-continuous dependent variable that does not satisfy the key assumptions in the linear regression analysis.

There are several methods to analyze the data involving binary outcomes. However, for this particular study, logit model was selected over discriminant and linear probability models. The linear probability model (LPM) which is expressed as a linear function of the explanatory variables is computationally simple. However, despite its computational simplicity, as recommended by [9] and [25], it has a serious defect in that the estimated probability values can lie outside the normal 0-1 range. Hence logit model is advantageous over LPM in that the probabilities are bound between 0 and 1 .

Moreover, logit best fits the non-linear relationship between the dependent and the explanatory variables. In the analysis of studies involving qualitative choices, usually a choice has to be made between logit and probit models. According to [9], the statistical similarities between logit and probit models make the choice between them difficult. The justification for using logit is its simplicity of calculation and that its probability lies between 0 and 1 . Moreover, its probability approaches zero at a slower rate as the value of explanatory variable gets smaller and smaller, and the probability approaches 1 at a slower and slower rate as the value of the explanatory variable gets larger and larger [25].

[27] pointed out that the logistic distribution (logit) has got advantage over the others in the analysis of dichotomous outcome variable in that it is extremely flexible and easily used model from mathematical point of view and results in a meaningful interpretation. In statistics, logistic regression, or logit regression, or logit model is a regression model where the dependent variable is categorical/binary dependent variable (most commonly called dummy variables) - that is, where it can take only two values, "0" and "1", which represent outcomes defaulter and non-defaulter.

Logistic regression was developed by statistician David Cox in 1958. The binary logistic model is used to estimate the probability of a binary response based on one or more predictor (or independent) variables (features). It allows one to say that the presence of a risk factor increases the probability of a given outcome by a specific percentage. Since the dependent variable of the study (loan payment) have binary/dichotomous outcomes (defaulter and non-defaulter), the binomial logistic regression model was selected for this study to find the determinant factors affecting loan repayment. 
The binomial logistic model is one of the sophisticated binary response model that overcomes the limitations of the LPM. In a binary response model, interest lies primarily in the response probability:

$$
\mathrm{P}(y=1 \mid \boldsymbol{x})=\mathrm{P}\left(y=1 \mid x_{1}, x_{2}, \ldots, x_{k}\right) \mid
$$

Where, $p(y=1 \mid x)$ is the probability that $y=1$ (non-defaulting) given $x$ (independent variable), $y$ represents loan repayment and $\mathrm{x}$ denote the full set of explanatory variables such as education level, method of lending, nearness of borrower's residence to the institutions, family size, loan size, loan diversion rate, income from activities financed by loan, interest rate, celebrating and participating on social festivals, and training that affect loan repayment.

To avoid the LPM limitations, let us consider a class of binary response models of the form:

$$
\mathrm{P}(y=1 \mid \boldsymbol{x})=G\left(\beta_{0}+\beta_{1} x_{1}+\ldots+\beta_{k} x_{k}\right)=G\left(\beta_{0}+\boldsymbol{x} \boldsymbol{\beta}\right) \mid \ldots
$$

Where, $G$ is a function taking on values strictly between zero and one: $0<\mathrm{G}(\mathrm{z})<1$, for all real numbers $\mathrm{z}$. This ensures that the estimated response probabilities are strictly between zero and one. We write $\mathrm{x} \beta=\beta_{1} \mathrm{X}_{1}+\ldots+\beta_{\mathrm{k}} \mathrm{X}_{\mathrm{k}}$. Logistic function is a nonlinear function that is used for the function $G$ in order to make sure that the probabilities are between zero and one. In the logit model, $G$ is the logistic function which is between zero and one for all real numbers $\mathrm{z}$. This is the cumulative distribution function for a standard logistic random variable:

$$
G(z)=\exp (z) /[1+\exp (z)]
$$

Where, $Z=X \beta=\beta_{1} x_{1}+\ldots+\beta_{k} x_{k}$

The goal logistic regression is to find the best fitting (yet biologically reasonable) model to describe the relationship between the dichotomous characteristic of interest (dependent variable=response or outcome variable) and a set of independent (predictor or explanatory) variables. Logistic regression generates the coefficients (and its standard errors and significance levels) of a formula to predict a logit transformation of the probability of presence of the characteristic of interest:

$$
\operatorname{logit}(p)=b_{0}+b_{1} X_{1}+b_{2} X_{2}+b_{3} X_{3}+\ldots+b_{k} X_{k}
$$

Logit(P) can be back transformed to $\mathrm{p}$ by the following formula:

- When one categorical variable and one independent variable is included:

$$
P(Y)=\frac{1}{1+e^{-\left(b_{0}+b_{1} x_{1}\right)}}
$$

- When one categorical variable and several independent variables is included in the study:

$$
P(Y)=\frac{e^{b_{0}+b_{1} x_{1}+b_{2} x_{2}+\ldots+b_{n} x_{n}}}{1+e^{b_{0}+b_{1} x_{1}+b_{2} x_{2}+\ldots+b_{n} x_{n}}}
$$

Where, $\mathrm{P}(\mathrm{Y})$ is probability of $\mathrm{Y}$ occurring, $\mathrm{e}$ is natural logarithm base $(\mathrm{e} \approx 2.71828 \ldots), \mathrm{b}_{0}$ is interception at $\mathrm{y}$-axis, $\mathrm{b}_{\mathrm{n}}$ is regression slope coefficient of $\mathrm{X}_{\mathrm{n}}$, and $\mathrm{X}_{\mathrm{n}}$ is predictor or independent variable that predicts the probability of $\mathrm{Y}$.

$$
P(Y)=\frac{e^{\beta 0+\beta 1 E D L}+\beta 2 M O L+\beta 3 N B R I+\beta 4 F S Z+\beta 5 L S Z+\beta 6 L D R+\beta 7 I N C O M+\beta 3 I N T R T+\beta 9 S O C F E S T+\beta 10 P L T}{1+e^{\beta 0+\beta 1 E D L}+\beta 2 M O L+\beta 3 N B R I+\beta 4 F S Z+\beta 5 L S Z+\beta 6 L D R+\beta 7 I N C O M+\beta 3 I N T R T+\beta 9 S O C F E S T+\beta 10 P L T}
$$

Since one categorical/dummy/binary dependent variable and eleven independent variables are included in this study, the binomial logistic regression model of this study becomes:

$\mathrm{P}(\mathrm{Y})$ denotes the probability of loan repayment (being non-defaulter). Logit model limits probabilities for values of dependent variable between 0 and $1 . \mathrm{X}_{\mathrm{i}}$ denotes the independent variables that influence loan repayment performance of borrowers. $\beta_{0}$ and $\beta_{\mathrm{i}}$, known as the parameters of the model, are, respectively, the intercept and slope coefficients.

\subsection{Description of variables and their scale of measurement}

From the theoretical and empirical literature, traditional observable characteristics that may influence the probability of being defaulter or non-defaulter (loan repayment performance) were summarized with their respective unit of 
measurement in table 2 below.

Table 2. Variables and their description

\begin{tabular}{|c|c|c|c|}
\hline Variables & Symbol & Unit of measurement & Expected sign/Hypotheses \\
\hline \multicolumn{4}{|c|}{ Dependent variable } \\
\hline Loan repayment & LP & Nominal & \\
\hline \multicolumn{4}{|c|}{ Explanatory variables } \\
\hline Education Level & EDL & Ordinal & + (high education level, high loan repayment performance) \\
\hline Method of Lending & MOL & Nominal & $\begin{array}{c}+ \text { (More individual lending scheme, better loan payment } \\
\text { performance ) }\end{array}$ \\
\hline $\begin{array}{l}\text { Nearness of Borrower's } \\
\text { Residence to Institution }\end{array}$ & NBRI & Nominal & $\begin{array}{c}+ \text { (less distance from the institutions, high the probability of } \\
\text { loan repayment performance) }\end{array}$ \\
\hline Family Size & FSZ & Continuous & $\begin{array}{c}\text {-(high family size }, \text { high probability of loan repayment } \\
\text { performance) }\end{array}$ \\
\hline Loan Size & LSZ & continuous & $\begin{array}{l}+ \text { (High loan amount, high the probability of loan repayment } \\
\text { performance) }\end{array}$ \\
\hline Loan Diversion Rate & LDR & nominal & $\begin{array}{c}+ \text { (Loan is used for intended purpose, High loan repayment } \\
\text { performance) }\end{array}$ \\
\hline $\begin{array}{l}\text { Income from activities financed } \\
\text { by loan }\end{array}$ & INCOM & Continuous & $\begin{array}{l}+ \text { (high income from activities financed by loan, high loan } \\
\text { repayment performance) }\end{array}$ \\
\hline Interest rate & INTRT & Continuous & $\begin{array}{c}\text { (High interest rate, low probability of loan repayment } \\
\text { performance) }\end{array}$ \\
\hline $\begin{array}{l}\text { Celebrating and participating on } \\
\text { social festivals }\end{array}$ & SOCFEST & Nominal & $\begin{array}{l}\text {-(high expenditure on social festivals, low probability of loan } \\
\text { repayment performance) }\end{array}$ \\
\hline Training & PLT & Nominal & $+($ Loan training, high loan repayment performance) \\
\hline
\end{tabular}

Source: own construct [2017]

\subsection{Methods of data Analysis}

Data analysis has been done after all the relevant data have been gathered from the respondents. The collected data were edited, coded and entered into a computer and processed by SPSS Version 21.0 statistical software. The empirical analysis of the study has been conducted using binary logistic regression model, which deals with loan repayment performance in total of 11 explanatory variables included in this study.

\subsection{Ethical Consideration}

The following ethical considerations have given attention by the researcher and enumerators while conducting the research or collecting the data:

- Privacy of participants [the privacy of the participants have been respected].

- Voluntary participation [no participants was forced to take part in the research and participants were free to withdraw from the research at any moment].

- No harm to participants [the researchers ensured that there is no any physical or psychological harm done to the participants as a result of the study].

- Anonymity and confidentiality [all information gathered during the study has been handled confidentially and permission from the participants was obtained for all information to be shared publicly].
- Not deceiving the subjects [participants have informed clearly about the aim, purpose and procedures of the study and was not deceived in any way].

\section{Results and Discussion}

A total of 364 questionnaires, three hundred fifty (350) have been appropriately filled and returned. This implies that the response rate for this study was seventy nine point forty three percent $(96.15 \%)$, which implies that highest proportion of respondents were participated in the process of data collection. This study employed binary logistic regression for data analysis.

\subsection{Regression result of Binary Logistic regression model}

Here, econometric analysis was undertaken in order to identify determinants of loan repayment performance of Microfinance institutions in Gedeo zone. As previously explained, binomial logistic regression was employed to estimate the effects of hypothesized explanatory variables on the loan repayment performance of beneficiaries in the MFIs in Gedeo zone.

The model was used to satisfy the specific objectives of the study i.e., to identify and examine demographic factors, cultural factors, loan factors, institutional factors and economic factors that determine the loan repayment performance of borrowers in the study area. 
Table 3. Regression result: dependent variable

\begin{tabular}{|c|c|c|c|c|c|c|c|c|}
\hline \multirow{2}{*}{ Independent Variables } & \multirow{2}{*}{ B } & \multirow{2}{*}{ S.E. } & \multirow{2}{*}{ Wald } & \multirow{2}{*}{ df } & \multirow{2}{*}{ Sig. } & \multirow{2}{*}{$\operatorname{Exp}(B)$} & \multicolumn{2}{|c|}{ 95\% C.I. for EXP(B) } \\
\hline & & & & & & & Lower & Upper \\
\hline EDL & $.208 * *$ & .122 & 2.903 & 1 & .088 & 1.231 & .969 & 1.563 \\
\hline MOL & $-.675^{* *}$ & .388 & 3.033 & 1 & .082 & .509 & .238 & 1.088 \\
\hline NBRI & $.894 *$ & .376 & 5.646 & 1 & .017 & 2.445 & 1.170 & 5.113 \\
\hline FSZ & $-.384 * *$ & .211 & 3.313 & 1 & .069 & .681 & .450 & 1.030 \\
\hline LSZ & .452 & .370 & 1.497 & 1 & .221 & 1.572 & .762 & 3.245 \\
\hline LDR & .325 & .423 & .592 & 1 & .442 & 1.384 & .604 & 3.172 \\
\hline INCOM & $.637 *$ & .260 & 6.006 & 1 & .014 & 1.892 & 1.136 & 3.150 \\
\hline INTRT & -.191 & .213 & .805 & 1 & .370 & .826 & .544 & 1.254 \\
\hline SOCFEST & .306 & .353 & .752 & 1 & .386 & 1.358 & .680 & 2.710 \\
\hline PLT & $.909 * *$ & .547 & 2.759 & 1 & .097 & 2.482 & .849 & 7.253 \\
\hline Constant & -2.579 & 2.421 & 1.135 & 1 & .287 & .076 & & \\
\hline
\end{tabular}

Number of observation: 350

$\mathrm{B}=$ regression coefficient

$\operatorname{Exp}(\mathrm{B})=$ odds ratio

Sig. $=$ significance

S.E. $=$ Standard error, -2 Loglikelihood $=222.028$

Cox \& Snell R Square $=.187$, Nagelkerke R Square $=.253$

$*$ and ** indicate that the coefficients are statistically significant at $5 \%$ and $10 \%$ level respectively

Source: binomial logistic regression model output, 2017

- Wald statistic: Alternatively, when assessing the contribution of individual predictors or independent variables in a binomial logistic regression model, one may examine the significance of the Wald statistic. The Wald statistic, analogous/comparable to the t-test in linear regression, is used to assess the significance of coefficients i.e., tests the effect of individual predictor while controlling other predictors. If the Wald statistic is located outside the lower and upper limit of a given confidence interval (99 percent or 95 percent or 90 percent), null hypothesis is rejected and the independent variable is significant. The reverse is true when Wald statistic is located within the interval. In this model, Wald statistic test is used to assess the significance of an individual predictor.

The Wald statistic is the ratio of the square of the regression coefficient to the square of the standard error of the coefficient and is asymptotically distributed as a chi-square distribution. Although several statistical packages (e.g., SPSS) report the Wald statistic to assess the contribution of individual predictors, the Wald statistic has limitations. When the regression coefficient is large, the standard error of the regression coefficient also tends to be large increasing the probability of Type-II error. The Wald statistic also tends to be biased when data are sparse.

- B: This is the coefficient for the constant (also called the "intercept") and the independent variables of the model. In binomial logistic regression, the regression coefficients represent the change in the logit for each unit change in the predictor. Given that the logit is not intuitive, focus is given for a predictor's effect on the exponential function of the regression coefficient - the odds ratio.

- S.E.: This is the standard error around the coefficient for the constant.

- Sig.: This is the chi-square test that determine whether the association between independent variable and depend variable is statistically significant by comparing the p-value (sometimes called the prob-value) of independent variable with the chosen significance level. The association is statistically significant and null hypothesis is rejected when the p-value (value listed in the column called "Sig.") is smaller than or equals to the specified significant level like .05 or .01 or 0.1 . Whereas, when p-value listed in the sig. column is greater than the specified significance level, the association between the independent variable and dependent variable is statistically insignificant.

- $\operatorname{Exp(B):~This~is~the~exponentiation~of~the~B~}$ coefficient, which is an odds ratio. This odds ratio is easier to interpret than the coefficient. It is used to interpret the relation between the independent variables and the probability that the dependent variable will be 1 . The odds in favor of an event occurring is defined as the probability the event will occur divided by the probability the event will not occur. The odds ratio measures the impact on the odds of a one-unit increase in only one of the independent variables as indicated by the following formula 


\subsection{Elaboration on Significant Explanatory Variables}

Table 4. Hypotheses and results of significant dependent variables

\begin{tabular}{|c|c|c|c|}
\hline Dependent Variables & Symbol & Expected sign/Hypotheses & Result from binomial logistic regression model \\
\hline Education Level & EDL & $\begin{array}{l}+ \text { (high education level, high loan } \\
\text { repayment performance) }\end{array}$ & $\begin{array}{l}\beta \text { of .208; positive association between education } \\
\text { level and loan repayment of MFIs' borrowers }\end{array}$ \\
\hline Method of Lending & MOL & $\begin{array}{l}+ \text { (More individual lending scheme, } \\
\text { better loan payment performance })\end{array}$ & $\begin{array}{l}\beta \text { of -.675; negative association between } \\
\text { individual oriented method of lending and loan } \\
\text { repayment of borrowers in MFIs }\end{array}$ \\
\hline $\begin{array}{l}\text { Nearness of Borrower's } \\
\text { Residence to Institution }\end{array}$ & NBRI & $\begin{array}{l}+ \text { (less distance from the institutions, } \\
\text { high the probability of loan repayment } \\
\text { performance) }\end{array}$ & $\begin{array}{l}\beta \text { of } .894 \text {; positive association between nearness } \\
\text { of borrower's residence to institution and loan } \\
\text { repayment of MFIs' borrowers }\end{array}$ \\
\hline Family Size & FSZ & $\begin{array}{l}\text { - (high family size, high probability } \\
\text { of loan repayment performance) }\end{array}$ & $\begin{array}{l}\beta \text { of }-.384 \text {; negative association between family } \\
\text { size and loan repayment of MFIs' borrowers }\end{array}$ \\
\hline $\begin{array}{l}\text { Income from activities } \\
\text { financed by loan }\end{array}$ & INCOM & $\begin{array}{l}+ \text { (high income from activities } \\
\text { financed by loan, high loan repayment } \\
\text { performance) }\end{array}$ & $\begin{array}{l}\beta \text { of .637; positive association between income } \\
\text { from activities financed by the loan and loan } \\
\text { repayment of MFIs' borrowers }\end{array}$ \\
\hline Training & PLT & $\begin{array}{c}+ \text { (Loan training, high loan repayment } \\
\text { performance) }\end{array}$ & $\begin{array}{l}\text { B of .909; positive association between training } \\
\text { and loan repayment of MFIs' borrowers }\end{array}$ \\
\hline
\end{tabular}

Source: own construct [2017]

\subsubsection{Demographic Factors}

1) Educational level (EDL): It was hypothesized that education is associated with loan repayment of MFIs. The result from binomial logistic regression model in the above table 3 and table 4 indicate positive sign for education level variable ( $\beta$ of .208), which implies positive association between education level and loan repayment MFIs. This shows that as level of education increases, borrowers enhance their ability to access, evaluate, and understand new production techniques and technologies. Since the Sig. statistic or p-value in some other statistical application (.088) is smaller than the chosen significance level ( 0.10 or 10 percent), the positive association between education level and loan repayment is statistically significant i.e., the level of education contributes to the variance in probability of borrower's loan repayment performance.

By another way, as Wald statistic of education level (2.903) is outside of 95 percent confidence interval (.969 $-1.563)$, the developed research hypothesis that there is significant association between education level and loan repayment is accepted. Hence, there is significant association between education level and loan repayment of MFIs. The result from binomial logistic model can be interpreted as, other variables being constant, increase in education level could lead loan repayment rate to be improved by 1.231. By other way, increase in one year schooling increases the odds ratio in favor of non-defaulting by a factor of 1.231 , ceteris paribus.

This implies that education plays great role in raising the level of awareness, exposure to technologies, access to business information and to manage resources properly which boost production and then improves loan repayment. Education level of the borrowers is one of the variables that were thought to affect loan repayment performance of the borrowers by different authors. This result is consistent with the findings of [3], [30], [48], [53], [34], but inconsistent with that of [44].

2) Nearness of borrower's residence to institution (DIS): It was hypothesized that there is significant association between nearness of borrower's residence to institution and loan repayment of MFIs. The result from binomial logistic regression model in the above table 3 and table 4indicate positive sign for nearness of borrower's residence to institution variable ( $\beta$ of .894), which implies positive association between nearness of borrower's residence to institution and loan repayment MFIs. This shows that as borrower's nearness to institution increases (become closer to the institution), the possibility of borrowers to repay their loan increases. Being closer with a lender's office will give an extra advantage to the lender and borrowers. This is because it is easy for the lender to monitor borrower's business and for borrowers to repay their loan.

Since the Sig. statistic or p-value in some other statistical application (.017) is smaller than the chosen significance level ( 0.05 or 5 percent), the positive association between nearness of borrower's residence to institution and loan repayment is statistically significant i.e., the nearness of borrower's residence to institution contributes to the variance or loan repayment performance of borrowers. By another way, as Wald statistic of nearness of borrower's residence to institution (5.646) is outside of 95 percent confidence interval $(1.170-5.113)$, the developed research hypothesis that there is significant association between nearness of borrower's residence to institution and loan repayment is accepted. Hence, there is significant association between nearness of borrower's residence to institution and loan repayment of borrowers' in MFIs. 
The result from binomial logistic model can be interpreted as, other variables remain constant, increase in nearness of borrower's residence to institution increases the borrowers' loan repayment probability by 2.445 . By other way, increase in nearness of borrower's residence to Microfinance institution increases the odds ratio in favor of loan repayment (being non-defaulter) by a factor of 2.445 , ceteris paribus. Nearness of the borrower's residence to Microfinance institution is one of the variables that thought to affect loan repayment performance of the borrowers by different authors. This result is consistent with the findings of [12], who found that distance of borrowers has significant effect on the loan default. But, it is against the findings of [26], [1] and [22], who indicated that the distance of borrowers from institutions doesn't have significant impact on the loan repayment problem.

3) Family size (FSZ): It was hypothesized that there is significant association between family size and loan repayment of MFIs. The result from binomial logistic regression model in the above table 3 and table 4 indicate negative sign for family size variable ( $\beta$ of -.384 ), that shows negative association between family size and loan repayment of MFIs. This shows that as borrower's family size increases, the probability of borrowers to repay their loan decreases. Having higher number of household members will increase consumption expenses and other living expenses which led loan repayment difficult.

Since the Sig. statistic or p-value (.069) is smaller than the chosen significance level ( 0.10 or 10 percent $)$, the negative association between family size and loan repayment is statistically significant i.e., having lower or higher number of household members or family size contributes to the change (increase or decrease) in probability of loan repayment performance of borrowers. By another way, as Wald statistic of family size (3.313) is outside of confidence interval $(.450-1.030)$, the developed research hypothesis that there is significant association between family size and loan repayment is accepted. Hence, there is significant association between family size and loan repayment of borrowers in MFIs.

The result from binomial logistic model can be interpreted as, other factors being equal, increase in family size lower the probability of borrowers' loan repayment by .681 . By other way, increase in family size increases the odds ratio in favor of loan defaulting by a factor of .681 , ceteris paribus. This result is consistent with the findings of [41] who have analyzed the determinants of repayment decision among small holder farmers in Southwestern State of Nigeria and obtained the result those borrowers with lower number of household members would meet their repayment obligation better than those with high number of household members.

In addition, the result of this study conforms to findings of [7] and [53] who argued that family size had negative influence on the level of loan repayment. However, the result of the model is inconsistent with the finding of [15], who argued that family size had insignificant effect on loan repayment performance of smallholder farmers.

\subsubsection{Economic Factor}

1) Income from activities financed by the loan (INCOM): The researcher hypothesized that income from activities financed by the loan is associated with loan repayment of MFIs. The coefficient from binomial logistic regression model in the above table 3 and table 4 indicate positive sign for this variable ( $\beta$ of .637), which implies positive association between income from activities financed by the loan and loan repayment MFIs. This shows that as the income from activities financed by the loan increases, borrowers enhance their ability to repay their loan on time.

Since the Sig. statistic or p-value in some other statistical application (.014) is smaller than the chosen significance level $(0.05$ or 5 percent), the positive association between income from activities financed by the loan and loan repayment is statistically significant i.e., the change in the level of income from activities financed by the loan contributes to the change in probability of borrower's loan repayment performance. On the other hand, as Wald statistic regarding income from activities financed by the loan (6.006) is outside of 95 percent confidence interval (1.136-3.150), the developed research hypothesis that there is no significant association between income from activities financed by the loan and loan repayment is accepted. Hence, income from activities financed by the loan and loan repayment of MFIs' borrowers has significant association.

The result from binomial logistic model can be interpreted as, other factors being constant, increase in income from activities financed by the loan could lead loan repayment rate to be improved by 1.892 . By other way, increase in income from activities financed by the loan increases the odds ratio in favor of non-defaulting by a factor of 1.892 , ceteris paribus. This result agrees with findings of [48], [53] and [30], who found out that income from activities financed by the loan is important and significant factor that enhances the credit repayment performance.

\subsubsection{Institutional Factors}

1) Method of lending (MOL): It was hypothesized that there is significant association between method of lending and loan repayment of MFIs. But, the result from binomial logistic regression model in the above table 3 and table 4 indicate negative sign of coefficient for this variable ( $\beta$ of -.675), that shows negative association between method of lending and loan repayment of borrowers in MFIs. This shows that as borrowers obtain loan individually, the probability to repay their loan decreases. If borrower obtained loan as per individual lending scheme, he or she will not obtain the support and 
guidance from the others and incentive to operate effectively as loan was taken individually. This negatively influences the probability borrower's loan repayment performance.

As the Sig. statistic or p-value (.082) is smaller than the chosen significance level ( 0.10 or 10 percent $)$, the negative association between method of lending and loan repayment is statistically significant i.e., obtaining loan as per individual lending scheme or group lending scheme contributes to the change (increase or decrease) in probability of loan repayment performance of borrowers. By another way, as Wald statistic of method of lending (3.033) is outside of confidence interval (.238-1.088), the developed research hypothesis that there is significant association between method of lending and loan repayment is accepted. Hence, there is significant association between method of lending and loan repayment of borrowers in MFIs.

The result from binomial logistic model done by SPSS version 21 can be interpreted as, other variables remain fixed, and obtaining loan as per individual lending scheme lowers the probability of borrowers' loan repayment by .509 . On the other hand, the odds ratio in favor of loan defaulting increases by factor of .509 , for borrowers who obtained loan individually, ceteris paribus. This finding is similar with most empirical findings such as [56], [46] and [43].

2) Training (PLT): The researcher hypothesized that there is significant association between training and loan repayment performance of borrowers in MFIs, and it is found to influence positively and significantly the borrower's loan repayment performance at 10 percent significance level. If other variables hold constant, the delivering of well-organized and sufficient training properly for borrowers increases the probability of borrower's loan repayment by 2.48 . By other way, other variables kept constant, the odds ratio favoring loan repayment performance increases by a factor of 2.482 for borrowers who were trained.

If lender provides various training, the clients will able to understand the rules and regulations easily. They can also develop skill on how to do business and money utilization. Training is needed not only for client but also for loan officers. In both cases, it has a positive contribution to the repayment rate. The model results show that this variable has a positive (as the coefficient of training i.e., $\beta$ of .909 have positive sign) impact on the loan repayment. This result agrees with the findings of [39], [12], [42],[52] and [6]. But, it disagrees with the result of [55] study, who reveals that there is statistically insignificant association between training and loan repayment performance.

\section{Conclusions}

According to the outputs of binomial logistic regression model done by the SPSS version 21 [see table 3 and table
4], education level, nearness of borrower's residence to institution, income from activities financed by the loan and training are positively related with loan repayment, whereas method of lending and family size have negative association with loan repayment. This study similarly evidenced that, other variables such as loan size, loan diversion rate, interest rate and celebrating and participating on social festivals were not significant determinants of loan repayment performance of borrower's Microfinance institutions. Hence, except H3, H8, H9 and H10, all research hypotheses are accepted.

\section{Scope for Further Research}

This study encourages further and comprehensive research into the interconnection between various demographic, economic, institutional factors, cultural, loan and other relevant factors, and loan repayment performance of borrowers in general. Also, there may be a need to test if there is some sort of association between loan repayment and purpose of borrowing. Additionally, this study has focused on certain variables related to determinants of loan repayment performance of borrowers. However, loan repayment performance on behalf of Microfinance institution was not extensively investigated. Thus, further researches can be conduct on this issue to breach the gap in this area. To provide basic information on the determinants of Microfinance institution beneficiaries' loan repayment problem, the social, political and environmental dimensions and specific characteristics that make rural borrowers of Microfinance institutions susceptible to loan default and their managing mechanisms demand future researchers' attention. The study exploits one time survey and no one be able to address the determinant factors of beneficiaries of MFI loan repayment problem in the area. Additional survey becomes crucial to make sure this finding is Consistent. Further study needs to incorporate beneficiaries from different MFIs found in different zones, regions and countries.

\section{Acknowledgements}

First, my innumerable praise goes to the Almighty God for giving me the opportunity, capacity and guidance throughout my life. I am very honorable to appreciate the sponsor of this study, Dilla University, which is one the first generation universities in Ethiopia that strive to produce knowledgeable graduates, to serve the community and to support problem solving researches thoroughly. My heart full thanks also goes to officers and borrowers of MFIs in Gedeo Zone for providing evidence and reliable data that is valuable for success of this study. It is also a great chance to express my deepest gratitude and thanks to my beloved mother, ALMAZ GUDETA for her support and help in fulfilling the necessary financial and all other 
needs in my life.

\section{REFERENCES}

[1] Abafita, J. (2003). Microfinance and Loan Repayment Performance: A Case Study of The Oromia Credit and Savings Share Company (Ocssco) In Kuyu. In: Addis Ababa.: Addis Ababa University.

[2] Abebe, B. (2002). Factors Influencing Loan Repayment of Rural Women In eastern Ethiopia: The Case of Dire Dawa Area.

[3] Abreham (2002) "Loan repayment and its Determinants in Small-Scale Enterprises Financing in Ethiopia: Case of private borrowers Around Zeway Area”, AAU.

[4] Addae-Korankye A. (2014). Causes and Control of Loan Default/Delinquency in Microfinance Institutions in Ghana..American International Journal of Contemporary Research, 4(12).

[5] Addisu M.(2006) "Micro-finance Repayment Problems in the Informal Sector in Addis Ababa." Ethiopian Journal of Business \& Development Volume 1 Number 2.

[6] Admassie, A. (2005). Rural finance in Ethiopia: Assessment of the financial products of microfinance institution. Association of Ethiopian Microfinance Institutions.

[7] Afolabi, J. A. (2010). Analysis of loan repayment among small scale farmers in Oyo State. Social Sciences Journal, pp. 115-119.

[8] African Development Bank (AfDB, 2012) the Five-Year Growth and Transformation Plan (GTP), of Ethiopia: African Economic Outlook.

[9] Amemiya, T. 1981. Qualitative Response Model: A Survey. Journal of Economic Literature. 19: 1483-1536

[10] Amha, W. (2000). Review of the Microfinance Industry in Ethiopia. Occasional paper 2 Association of Ethiopian Microfinance Institutions (AEMFI).

[11] Amha W. (2008). Innovations in the delivery of financial services through the deposit taking microfinance institutions (MFIs) in Ethiopia.

[12] Assefa B. (2002). Fctors influencing loan repayment of rural women in Eastern Ethiopia: The case of Dire Dawa Area, A thesis presented to the school of graduate studies, Aremaya university, Ethiopia.

[13] Beaudry, S. (2008). Microfinance: A guide for grant makers.. [Online] Available at: http://www.gwob.net/news/GWOB Microfinance Guide.pdf [Accessed 6, 1, 2017].

[14] Belay Abebe (2002), Factors Influencing Loan Repayment of Rural Women In eastern Ethiopia: The Case of Dire Dawa Area, Msc Thesis Haromaya University.

[15] Berhanu A., Fufa B. (2008). Repayment rate of loans from semi-formal financial institutions among small-scale farmers in Ethiopia. Two-limit Tobit analysis. J.soc.Econ.
$37: 2221-2230$.

[16] Besley, T., \& Coates, S. (1995). Group lending, repayment incentives and social collateral. Journal of Development Economics, 46, 1-18.

[17] Bhattacherjee, A. (2012). Social Science Research: Principles, Methods, and Practices, 2nd Ed. Switzerland.

[18] Bond, P., \& Rai, A. (2009). Borrower runs.. Journal of Developmental Economy, Volume 88, pp. 185-199.

[19] Bryman, A. (2004). Social Research Methods (2nd Edition ed.). New York: Oxford University Press.

[20] Chowdhury, P.R. (2005). Group lending: sequential financing, lender monitoring and joint liability.Journal of Development Economics.

[21] Diagne, A., Chimombo, W., Simtowe, F., \& Mataya, C. (2000). Design and sustainability issues of rural credit and saving programs for the poor in Malawi: an action-oriented research project. Washington, DC: IFPRI..

[22] Fikirte Reta. (2011) Determinate Of Loan Repayment Performance: A Case Study of The Addis Credit and Saving Institution (ADCIS) In Addis Ababa, Msc Thesis, Wegeningen University, Netherlands.

[23] Ghataka M. and Guinnane W.T.(1999). The economics of lending with joint liability: theory and practice. Journal of Development Economics. Vol. 60, 195-228

[24] Godquin, M. (2004). Microfinance Repayment Performance in Bangladesh: How to Improve the Allocation of Loans by MFIs. World Development, Volume 32, p. 1909-1926.

[25] Gujarati, D. N. (1995). Basic Econometrics. 3rd Edition ed New York: McGraw-Hill,.

[26] Haile F. (2015). Determinants of loan repayment performance case study of Harari microfinance institutions. Journal of agricultural extension and rural development.

[27] Hosmer Lemeshow (1998) Applied Logistic Regression, 2nd Ed. University of Massachusetts and the Ohio State University, Massachusetts and Columbus http://www.Bu.Cam.Uk/Winbugs/Cont.Shml (Accessed on 27 April, 2017).

[28] Hunte, C. K. (1996). Controlling loan default and improving the lending technology in credit institution: AEMFI. Saving and Development.

[29] Israel G. (1992). sampling the evidence of extension program impact, Program evaluation and organizational Development', Institution of Food and Agricultural science (IFAS).

[30] Jemal Abafita (2003) Microfinance and Loan Repayment Performance: A Case Study of The Oromia Credit and Savings Share Company (Ocssco) In Kuyu, Msc Thesis, Addis Ababa University, Addis Ababa.

[31] Khandker, S. (2000). Fighting poverty with microcredit.

[32] Kohansal, M.R. and Mansoori, H. (2009). Factors Affecting on Loan Repayment Performance of Farmers in Khorasan , Natural Resource Management and Rural Development. Razavi, s.n. 
[33] Mersland, R., \& Strom, R.O. (2008). Performance and trade-offs in microfinance organizations does ownership matter?.Journal of International Development, Volume 20, pp. 598-612.

[34] Million, S., Nyikal, R., \& Wania, S. (2012). Factors affecting loan repayment performance. Developing Countries Studies. pp. 4-10.

[35] Mohamed, K. (2003). Research on poverty alleviation: Access to formal and quasi-formal credit by smallholder farmers and artisanal fishermen.

[36] Mugenda, O. M. \&. M. A. (2003). Research methodology. Nairobi: Nairobi Press.

[37] Natukunda, J. (2010). Microcredit lending terms: How to reduce arrears in microfinance institutions. Journal of Microfinance, Volume 3, pp. 614-628.

[38] Nawai, N. and Shariff, M. N. M. (2013). Loan Repayment Problems in Microfinance Programs that use Individual Lending Approach: A Qualitative Analysis.Journal of Transformative Entrepreneurship, 1(2), pp. 93-99.

[39] Norell D. (2001). How to reduce arrears in microfinance institutions. pp. 115-130.

[40] [40], Oladeebo, J. O., \& Oladeebo, O. E. (2008). Determinants of loan repayment among smallholder farmers in Ogbomosho agricultural zone of Oyo state. Social Sciences Journal, pp. 59-62.

[41] Olagunju, F. I., \& Adeyemo, R. (2007). Determinants of repayment decision among small holder farmers in Southwestern Nigeria. Medwell Journals, pp. 677-686.

[42] Onyeagocha, S., \& Chidebelu, D. (2012). Determinants of loan repayment of microfinance. International Journal of Science and Humanities, 1(1), pp. 3-6.

[43] Rejaul A. and Karim H.B. (2008). 'No collateral No loan' to 'No collateral No default': The economics of group lending micro finance.journal of social sciences, 3(8), pp. 611-625.

[44] Reta, F. (2011). Determinate of Loan Repayment Performance: A Case Study of The Addis Credit and Saving Institution (ADCIS) In Addis Ababa.

[45] RUFIP (2005). Loan appraisal and delinquency management.

[46] Saloner, R. (2007). Microfinance in the Developing World: The Effect of Institutional Characteristics on Default Rate.
Stanford: Stanford University Press.

[47] Samuel Setargie Amera (2008). Credit Default Risk and Its Determinants of Microfinance Industry in Ethiopia.

[48] Samuel, S. A. (2011). Credit default risk and its determinants of microfinance industry in Ethiopia.

[49] Sengupta, R., \& Aubuchon, C.P. (2008). The microfinance revolution: An overview. :Federal Reserve Bank of st. Louis review, pp. 9-30.

[50] Sylvester, I., Okpara, C., \& Chukwudi, J. (2013). Determinants of loan repayment performance. Advances in Economics and Business Journal, 2 (1), 14-21.

[51] Solomon Alemu and Addisu Bajira (2013). Determinants of Rural Households Loan Repayment Performance, In Oromia National Regional State: The Case of Dodota Woreda. International Journal of Research in Computer Application \& Management, Volume 3.

[52] Statham, C. (2008). The benefits of business training for microfinance institutions. Economic Journal Article, 44(4), pp. 614-628.

[53] Tnsue, G. (2011). Determinants of loan repayment in microfinance institutions.

[54] Warue, B.N. (2012). Factors affecting loan delinquency in Microfinance in Kenya. International Journal of Management Sciences and Business Research.

[55] Welderufael L., Dr. Tesfatsion S. and Gedifew A. (2015). Factors Influencing MFIs Group Loan Repayment Performance: A Case of MSEs' Service Sector in Mekelle City, Ethiopia. Research Journal of Finance and Accounting, Volume 6.

[56] Woolcock, M. (2001). Microenterprise and social capital: A framework for theory, research, and policy. Journal of Socio-Economics , pp. 193-198.

[57] www.statisticshowto.com $>$ find-sample-size/

[58] Zelalem Gebeyehu ,Hassen Beshire and Jema Haji (2013), Determinants Of Loan Repayment Performance of Small Holder In Ethiopia, International Journal Of Economics and Finance Vol.1 No.11, December, 2013, Pp.431-446.

[59] Zeller M. (1996). Determinants of repayment performance in credit groups. The role of program design, intra-group risk pooling and social cohesion in Madagascar', international food policy research institute Washington, DC, USA. 